\title{
PENGENDALIAN BANJIR DI SUB DAS JEROAN KABUPATEN MADIUN
}

\author{
Vindha Bagus Devianto ${ }^{1)}$, Donny Harisuseno ${ }^{2)}$ Runi Asmaranto ${ }^{2)}$ \\ ${ }^{1)}$ Staff Dinas Pekerjaan Umum dan Penataan Ruang Kabupaten Madiun \\ ${ }^{2)}$ Dosen Teknik Pengairan, Fakultas Teknik, Universitas Brawijaya \\ E-mail : vindha_bagus@yahoo.com ${ }^{1)}$, donnyhari@yahoo.com ${ }^{2)}$, runi_asmaranto@ub.ac.id ${ }^{2)}$
}

\begin{abstract}
ABSTRAK: Banjir merupakan peristiwa alam yang dapat menimbulkan kerugian harta benda penduduk serta korban jiwa. Kondisi tersebut terjadi di sub DAS Jeroan di Kabupaten Madiun, dimana berdasarkan data yang diperoleh menunjukkan bahwa selama 12 tahun terakhir, banjir terbesar terjadi pada tahun 2007. Kajian ini bertujuan untuk menganalisa upaya pengendalian banjir di sub DAS Jeroan. AVSWAT 2000 digunakan untuk menghitung debit puncak banjir akibat pengaruh perubahan tataguna lahan, sedangkan debit banjir rancangan digunakan HSS Nakayasu dengan verifikasi dilakukan berdasarkan data debit banjir historis AWLR Jeroan. Untuk mengetahui kapasitas tampungan sungai Jeroan dilakukan analisis profil muka air dengan bantuan HEC-RAS 5.0.1. Hasil kajian simulasi pemodelan AVSWAT 2000 menunjukkan terjadi fluktuasi debit puncak banjir berdasarkan perubahan tataguna lahan tahun 2006, 2009, 2012 dan 2015. Debit kala ulang banjir yang mendekati debit historis (AWLR) adalah debit kala ulang 25 tahun sebesar $296,967 \mathrm{~m}^{3} / \mathrm{dt}$. Dengan simulasi HEC-RAS 5.0.1 kapasitas sungai Jeroan tidak dapat menampung debit kala ulang 25 tahun di beberapa patok yang mengakibatkan genangan di lahan sebesar $5.169 .952 \mathrm{~m}^{3}$. Pengendalian banjir dilakukan dengan pembuatan bendungan di 2 (dua) lokasi di hulu sub DAS Jeroan dan normalisasi sungai serta pembuatan tanggul sungai di hilir Sub DAS Jeroan.
\end{abstract}

Kata kunci: Tataguna lahan, AVSWAT 2000, HEC-RAS 5.0.1, Pengendalian Banjir

\begin{abstract}
Floods are natural events that may cause loss of civilian property and lives. The condition occurs in the sub-basin Jeroan in Madiun Regency, which according to record for 12 years took place in 2007. The present study has an objective to determine the effect of land use change on flood peak discharge, calculate the return period flood discharge, analyze storage capacity to accommodate the discharge of the river Jeroan return period flood and flood control efforts in sub-basins Jeroan. AVSWAT 2000 used to calculate flood peak discharge due to the effects of changes in land use, while the design flood discharge is used HSS Nakayasu with verification carried out based on historical flood discharge record Jeroan AWLR. To determine the storage capacity of the Jeroan river water surface profile analysis is done with the help of HEC-RAS 5.0.1. The results of simulation modeling study showed a fluctuating AVSWAT 2000 flood peak discharge by the land use change. Return period of flood discharge conform with historical discharge (AWLR) is a 25 year return period with discharge of $296.967 \mathrm{~m}^{3} / \mathrm{sec}$. The result of HEC-RAS 5.0.1 simulation showed that Jeroan river capacity could not accommodate discharge with return period of 25 years in several cross sections which subsequently caused land inundation that encompass 5,169,952 $\mathrm{m}^{3}$ of volume. Flood control is conducted by constructed dam at two locations in upstream of sub-basin Jeroan and river normalization as well as the construction of river embankments in downstream of sub-basin Jeroan.
\end{abstract}

Keywords:Land use, AVSWAT 2000, HEC-RAS 5.0.1, Flood Control

DAS bagian hulu seringkali menjadi fokus perencanaan pengelolaan DAS mengingat bahwa dalam suatu DAS, daerah hulu dan hilir mempunyai keterkaitan biofisik melalui daur hidrologi (Asdak, 2002:12). 
Dampak dari aktivitas pengelolaan DAS yang diselenggarakan di daerah hulu seperti perubahan tata guna lahan yang tidak memperhatikan sistem konservasi yaitu penurunan produktivitas tanah dan air di daerah hulu, dan juga akan menimbulkan pendangkalan sungai di daerah hilir yang memicu terjadi banjir.

Taruna satya (2014) menjelaskan adanya lahan kritis cenderung meningkatkan erosi, yang berakibat pada meningkatnya sedimentasi sungai, menurunkan daya tampung sungai, sehingga timbul kawasan-kawasan rawan luapan air atau kawasan rawan banjir.

Gina (2013) mendefinisikan bahwa kondisi topografi, penggunaan lahan, dan jenis tanah mempengaruhi besarnya limpasan yang terjadi pada DAS.

Banjir terjadi jika kapasitas tampang sungai tidak cukup untuk menampung besarannya debit banjir (Istiarto, Gunawan D.W, 2007).

Pemanfaatan lahan yang melebihi kemampuan tanah setidaknya akan menimbulkan perubahan-perubahan dalam ekosistem, sehingga terjadi penurunan daya dukung lingkungan (Sulfandi, 2015). Dan hal ini tercermin di antaranya pada kondisi di sub DAS Jeroan.

Sungai Jeroan merupakan salah satu anak sungai Madiun yang ada di wilayah Kabupaten Madiun. Usaha-usaha pemerintah untuk meningkatkan kenyamanan daerah agar terbebas dari suatu bencana tanah longsor dan banjir sudah banyak dilakukan diantaranya dengan normalisasi sungai Jeroan, pembuatan tanggul, parapet, pemasangan pintu kleb dan pompa. Namun karena telah terjadi perubahan alam (tata guna lahan) termasuk perubahan karakteristik sungai, sehingga hampir setiap tahun terdengar berita khususnya kejadian banjir yang menenggelamkan sarana dan prasarana daerah dan merusak lahan pertanian serta menghanyutkan permukiman penduduk khususnya di bagian hilir sungai Jeroan.

Dimana kejadian banjir ini juga didukung oleh lokasi terjadinya genangan air yang berada di pertemuan sungai yaitu sungai Madiun dan sungai Jeroan. Sungai Madiun juga mempengaruhi sungai Jeroan terutama pada musim hujan yang mengakibatkan meluapnya sungai Jeroan akibat terjadinya air pasang dari sungai Madiun.

Berdasarkan permasalahan tersebut, maka penelitian dalam kajian ini memiliki tujuan mengetahui pengaruh perubahan tataguna lahan terhadap debit puncak di sub DAS Jeroan tahun 2006, 2009, 2012 dan 2015, mengetahui kala ulang debit banjir yang terjadi di sungai Jeroan, mengetahui kapasitas eksisting sungai Jeroan dalam menampung debit banjir dan memberikan rekomendasi penanganan dalam mereduksi genangan air di sub DAS Jeroan akibat banjir.

\section{BAHAN DAN METODE Lokasi Studi}

Lokasi yang akan digunakan sebagai tempat penelitian adalah sungai Jeroan yang merupakan sub DAS dari sungai Madiun yang berada di Kabupaten Madiun (Gambar 1). Untuk memudahkan identifikasi daerah studi, dibagian hilir sungai Jeroan terdapat bangunan AWLR Jeroan. Maka daerah yang berada diatas AWLR Jeroan dinamakan Sub DAS Jeroan dengan panjang sungai utama $\pm 49.86 \mathrm{~km}$ dan luas Daerah Aliran Sungai (DAS) $\pm 268.57 \mathrm{~km}^{2}$ yang berasal dari beberapa mata air yang ada di lereng gunung Wilis.

Data-data yang digunakan dalam penelitian ini mencakup data primer dan sekunder. Dimana data primer mencakup interpretasi peta tataguna lahan (bersumber dari citra landsat), data TMA (tinggi muka air) historis tertinggi di pertemuan sungai dan data tinggi genangan dibeberapa titik sebaran. Sedangkan data sekunder mencackup data hujan, data tinggi muka air (AWLR Jeroan), peta tataguna lahan, peta jenis tanah, peta topografi dan data geometri sungai.

\section{Interpretasi Citra Satelit}

Interpretasi citra satelit diperlukan untuk mengolah data citra menjadi peta tataguna lahan. Proses interpretasi citra satelit menjadi peta tataguna lahan menggunakan software Envi 5.1 dan ArcGIS 10.1. Tahapannya meliputi: (1) Koreksi Radiometrik Citra, (2) Reduksi Bising (Noise Reduction), (3) Pembuatan Komposit Citra, (4) Penajaman Citra, (5) Pemotongan Citra dan (6) Klasifikasi Citra.

\section{AVSWAT 2000 (ArcView Soil and Water Assessment Tool) \\ AVSWAT 2000 (ArcView Soil and} Water Assessment Tool) adalah sebuah software yang berbasis Sistem Informasi Geografis (SIG) ArcView 3.x (ESR1) sebagai exstension (graphical user interface) di dalamnya. 
Program ini di keluarkan oleh Texas Water Resources Institute, College Station, Texas, USA. ArcView sendiri adalah salah satu dari sekitar banyak program yang berbasis Sistem Informasi Geografis (SIG). AVSWAT dirancang untuk memprediksi pengaruh manajemen lahan pada aliran air, sedimen, dan lahan pertanian dalam suatu hubungan yang kompleks pada suatu Daerah Aliran Sungai (DAS) termasuk di dalamnya jenis tanah, tata guna lahan dan manajemen kondisi lahan secara periodik (Suhartanto, 2008:6).

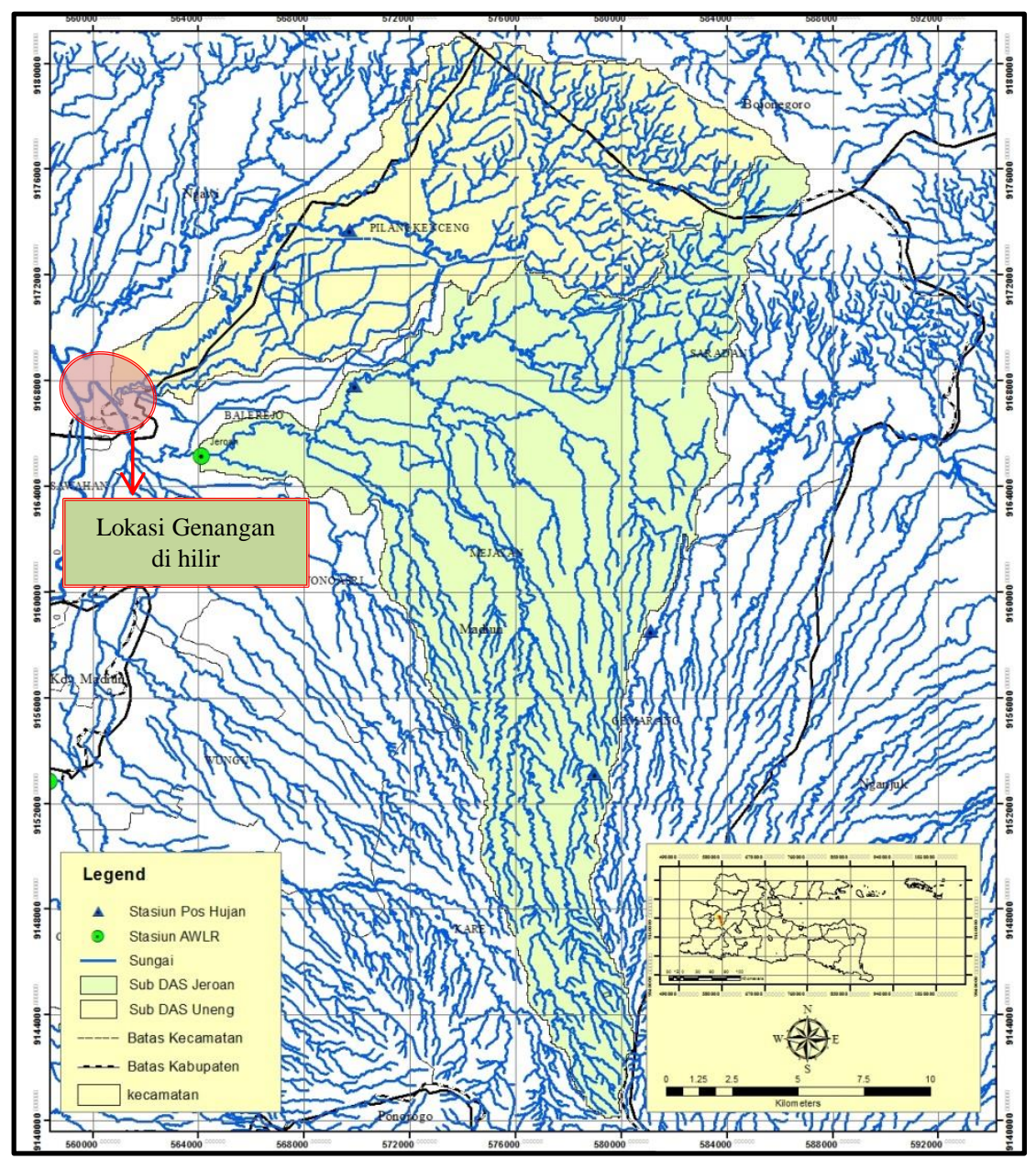

Gambar 1 Lokasi Penelitian

\section{Analisa Debit Banjir Rancangan}

Pada kajian ini debit banjir dihitung dengan menggunakan metode hidrograf satuan sintetis Nakayasu dengan ilustrasi hidrograf seperti pada Gambar 2. Besarnya nilai debit puncak hidrograf satuan dihitung dengan rumus (Soemarto, 1999: 169):

$$
\mathrm{Qp}=\frac{C \cdot A R_{0}}{3,6\left(0,3 T p+T_{0,3}\right)}
$$

Dimana Qp merupakan debit puncak banjir $\left(\mathrm{m}^{3} /\right.$ det), A merupakan luas DAS (sampai ke outlet) $\left(\mathrm{km}^{2}\right), \mathrm{R}_{0}$ merupakan curah hujan satuan $(\mathrm{mm}), \mathrm{Tp}$ merupakan tenggang waktu dari permulaan hujan sampai puncak banjir (jam)

$$
\mathrm{Tp}=\operatorname{tg}+0,8 \operatorname{tr}
$$

tg merupakan waktu konsentrasi (jam), tenggang waktu dari titik berat hujan sampai titik berat hidrograf (time lag) dalam hal ini, jika:

$$
\begin{array}{ll}
\mathrm{L}<15 \mathrm{~km} & \operatorname{tg}=0,21 . \mathrm{L}^{0,7} \\
\mathrm{~L}>15 \mathrm{~km} & \operatorname{tg}=0,4+0,058 . \mathrm{L}
\end{array}
$$

tr merupakan tenggang waktu hidrograf (time base of hidrograf) dimana 0,5 sampai $1 \mathrm{tg}$ (jam)

$$
\mathrm{T}_{0,3}=\alpha \cdot \mathrm{Tg}
$$

untuk:

daerah pengaliran biasa $\alpha=2$ 
bagian naik hidrograf yang lambat dan bagian menurun yang cepat $\alpha=1,5$

bagian naik hidrograf yang cepat dan bagian menurun yang lambat $\alpha=3$

Bagian lengkung naik (rising limb) hidrograf satuan memiliki rumus:

$$
\mathrm{Qa}=\mathrm{Qp}\left(\frac{\mathrm{t}}{\mathrm{Tp}}\right)^{2,4}
$$

Keterangan:

$\mathrm{Qa}=$ limpasan sebelum mencapai debit puncak $\left(\mathrm{m}^{3} / \mathrm{det}\right)$

$\mathrm{t}=$ waktu jam

Bagian lengkung turun (decreasing limb) hidrograf satuan

$$
\begin{aligned}
\mathrm{Q}_{\mathrm{d} 1} & =\mathrm{Qp} \times 0,3^{\frac{\mathrm{t}-\mathrm{Tp}}{\mathrm{T}_{0,3}}} \\
\mathrm{Q}_{\mathrm{d} 2} & =\mathrm{Qp} \times 0,3^{\frac{\mathrm{t}-\mathrm{T} \mathrm{p}+0,5 \mathrm{~T}_{0,3}}{1,5 \mathrm{~T}_{0,3}}} \\
\mathrm{Q}_{\mathrm{d} 3} & =\mathrm{Qp} \times 0,3^{\frac{\mathrm{t}-\mathrm{T} \mathrm{p}+1,5 \mathrm{~T}_{0,3}}{2 \mathrm{~T}_{0,3}}}
\end{aligned}
$$

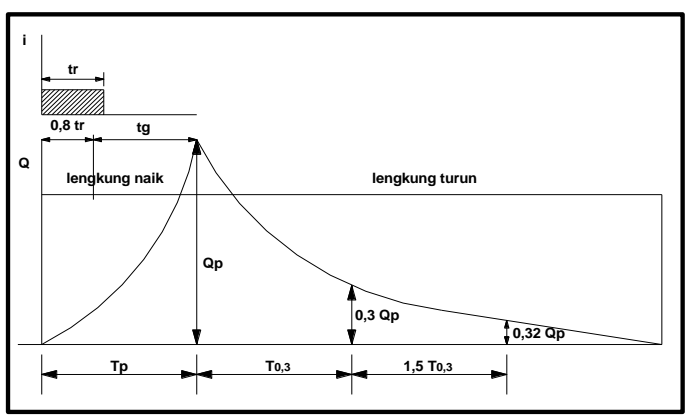

Gambar 2 Lengkung HSS Nakayasu

\section{Program HEC-RAS 5.0.1}

Dalam buku panduan HEC-RAS, HECRAS merupakan program aplikasi untuk memodelkan aliran air di sungai, River Analysis System (RAS), yang dibuat dan dikembangkan oleh Hydrologic Engineering Center (HEC), yang merupakan bagian dari Institute for Water Resources (IWR), dibawah U.S. Army Corps of Engineers (USACE).

Program ini adalah program yang didesain untuk menjalankan perhitungan hidraulik satu dimensi dan dua dimensi untuk jaringan sungai/saluran alami maupun saluran buatan. HEC-RAS memiliki lima komponen analisa sistem sungai antara lain simulasi perhitungan aliran tetap (Steady Flow), simulasi perhitungan aliran tidak tetap (Unsteady Flow), simulasi transport sedimen (Sediment Transport), simulasi kualitas air (Water Quality) dan Floodplain Mapping

\section{Pengendalian Banjir}

Debit banjir $\left(\mathrm{Q}, \mathrm{m}^{3} / \mathrm{dt}\right)$ adalah fungsi dari kecepatan aliran banjir (V, m/dt) dan luas penampang sugai (A, m). Jadi upaya pengendalian banjir dapat dilakukan dengan pendekatan terhadap tiga komponen tersebut. Adapun dalam kajian ini dilakukan pengendalian berupa mengatur debit puncak banjir $\left(\mathrm{Q}, \mathrm{m}^{3} / \mathrm{dt}\right)$, misalnya dengan waduk dan memperbesar luas penampang sungai dengan normalisasi dan pembuatan tanggul. Penentuan lebar rencana sungai adalah merupakan salah satu tahap perencanaan perbaikan dan pengaturan sungai yang paling penting. Lebar sungai dinyatakan sebagai fungsi dari debit sungai dengan persamaan sebagai berikut (sosrodarsono, 1994:329)

$$
\mathrm{B}=\alpha \mathrm{Q}^{1 / 2}
$$

Dimana B merupakan lebar sungai (m), $\alpha$ merupakan koefisien (grafik dari buku sosrodarsono, 1994:329) dan Q merupakan debit $\left(\mathrm{m}^{3} / \mathrm{dt}\right)$. Sedangkan perencanaan lebar puncak tanggul dan tinggi jagaan tanggul ditentukan berdasarkan standar perencanaan tanggul.

\section{Pengolahan Data}

Tahapan analisis pada kajian ini meliputi input data AVSWAT 2000, pembuatan DAS (Catchment Area), pengolahan peta tataguna lahan dan jenis tanah, melakukan simulasi Run SWAT dari menu simulation AVSWAT 2000, melakukan kalibrasi debit model dengan debit terukur AWLR jeroan, menentukan kala ulang debit banjir rancangan, menganalisa kemampuan kapasitas sungai eksisting dengan bantuan program HEC-RAS 5.0.1, merekomendasikan dan menganalisa pengendalian banjir.

\section{HASIL DAN PEMBAHASAN Interpretasi Citra Secara Digital}

Mempersiapkan Peta Landsat 8 OLI (Operational Land Imager) tahun 2015 (Gambar 3) yang meliputi wilayah sub DAS Jeroan setelah melakukan koreksi radiometrik citra dan koreksi geometrik proses selanjutnya Penajaman citra.

Setelah dilakukan penajaman citra selanjutnya dilakukan pemotongan citra dan membuat training area. Pada studi ini unsur klasifikasi (kunci interpretasi) dari citra landsat 8 dengan kombinasi komposit band 1, 5 dan 6 dan dibagi menjadi 7 kelas penggunaan lahan. 
Hasil klasifikasi dibandingkan hasil pengamatan, sebaran titik pengamatan di lapangan dalam studi ini sebanyak 22 titik (Gambar 4).

Dari hasil perbandingan pengamatan lapangan selanjutnya dihitung tingkat keakuratan dalam interpretasi sebesar $\frac{18}{22} \times$ $100 \%=81,82 \% . \quad$ Klasifikasi sudah disesuaikan dengan hasil pengamatan dilapangan.

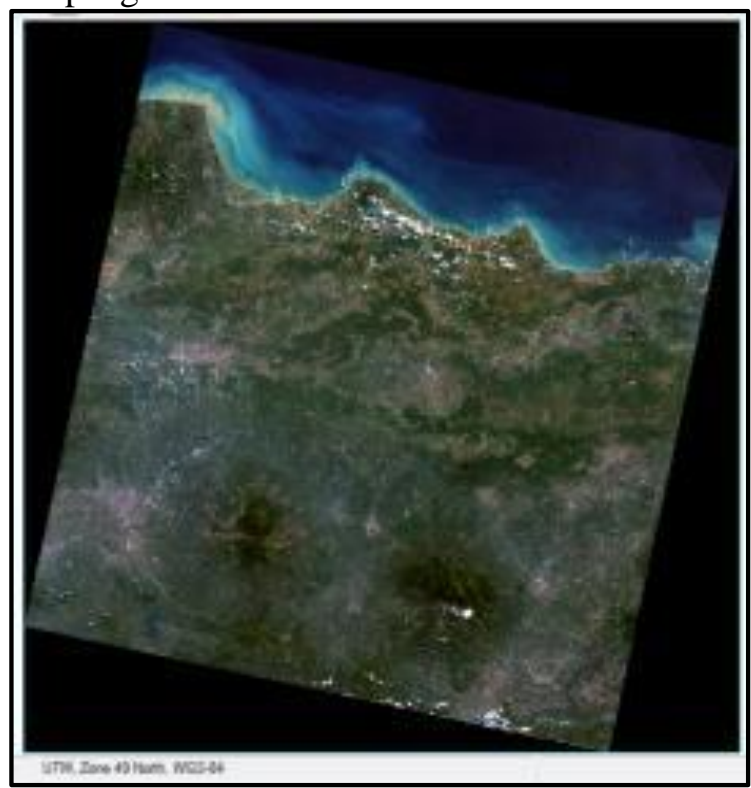

Gambar 3 Citra Landsat 8 OLI (Operational

Land Imager) Tahun 2015 wilayah studi (pathrow 119-065)

Sumber: http://earthexplorer.usgs.gov

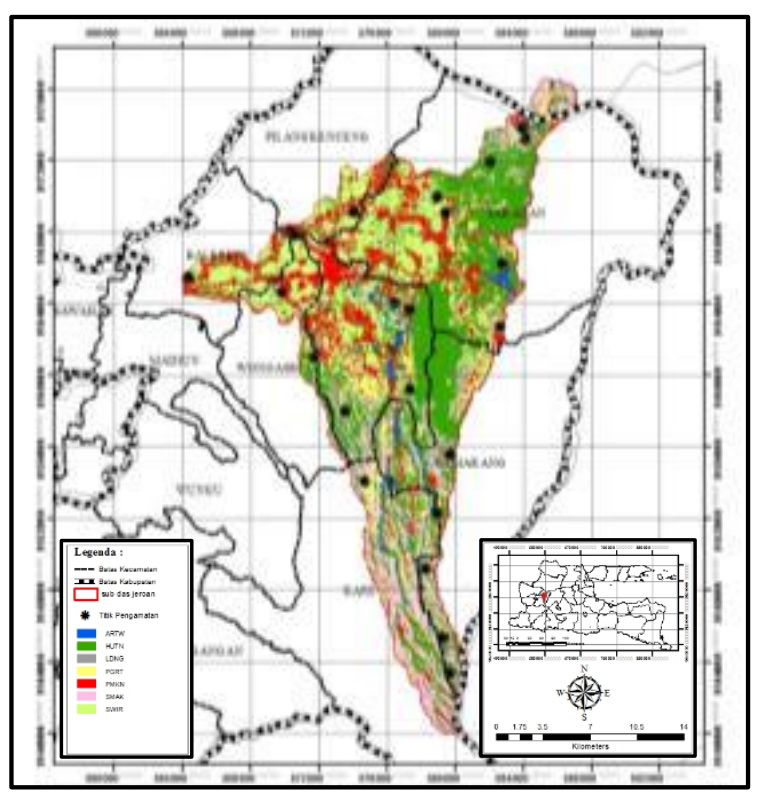

Gambar 4 Sebaran Titik Pengamatan di Lokasi Studi

Sumber: hasil analisa

\section{Analisa Debit Puncak Dengan AVSWAT 2000}

Pembuatan batas DAS dilakukan dengan menjalankan perintah watershed delineation dalam program AVSWAT, dimana membutuhkan data DEM (dalam bentuk grid), peta sungai dan outlet (dalam kajian ini digunakan lokasi AWLR Jeroan sebagai outlet).

AVSWAT 2000 membutuhkan informasi mengenai karakteristik suatu DAS antara lain hujan dan lokasi pos hujan (Tabel 1), penggunaan lahan (Tabel 3) dan jenis tanah.

Tabel 1 Koordinat Stasiun Hujan

\begin{tabular}{|c|l|c|c|c|}
\hline \multirow{2}{*}{ No } & \multicolumn{1}{|c|}{ Nama Stasiun } & \multicolumn{2}{|c|}{ Koordinat UTM } & \multirow{2}{*}{ Elevasi } \\
& \multicolumn{1}{|c|}{ Hujan } & XPR & YPR & \\
\hline 1 & Sta. Kuwu & 569909.1255 & 9167805.041 & 63 \\
\hline 2 & Sta. Gemarang & 581096.1058 & 9158523.61 & 300 \\
\hline 3 & Sta. Cermo & 579006.1966 & 9153114.421 & 144 \\
\hline
\end{tabular}

Sumber: UPT PSDA WS Madiun

Proses simulasi pemodelan dengan menggunakan AVSWAT 2000 dilakukan dalam 2 proses, yang meliputi simulasi awal dengan menggunakan nilai-nilai default yang ada pada model AVSWAT 2000, dan simulasi setelah kalibrasi, yaitu dengan menggunakan nilai-nilai parameter dari proses simulasi awal yang ditambah dengan input faktor dan parameter yang mempengaruhi besaran debit inflow model (Tabel 2).

Tabel 2 Parameter Kalibrasi AVSWAT 2000

\begin{tabular}{|l|l|c|}
\hline \multicolumn{2}{|c|}{ Parameter } & Koefisien \\
\hline HRU & LAT_TIME & 180 \\
\cline { 2 - 3 } & ESCO & 1 \\
\hline MGT & CN2 & $\begin{array}{c}\text { Diturunkan 35 \% dari nilai } \\
\text { default, kecuali CN = 35 }\end{array}$ \\
\hline
\end{tabular}

Sumber: Analisa

Parameter kalibrasi memberikan perubahan yang cukup signifikan terhadap perubahan debit model seperti Gambar 5. Keluaran dari suatu model setelah dikalibrasi, sebelum digunakan harus dievaluasi secara statistik terlebih dahulu terhadap data lapangan. Hal ini dilakukan untuk mengetahui kesesuaian model dengan data lapangan, dan untuk menghindari penyimpangan yang terlalu besar antara hasil model dengan data lapangan. Untuk menguji keandalan model, dalam penelitian ini digunakan Analisis regresi, Mean Absolut Error (MAE), Koefisien Performance (CP), dan Nash-Sutcliffe Efisiensi (NSE). Hasil beberapa metode evaluasi ketelitian model AVSWAT dapat dilihat pada Tabel 4. 
Tabel 3 Sebaran Tataguna Lahan

\begin{tabular}{|c|c|c|c|c|c|c|c|c|c|}
\hline \multirow{3}{*}{ NO } & \multirow{3}{*}{ Jenis Peruntukan } & \multicolumn{8}{|c|}{ Tata Guna Lahan } \\
\hline & & \multicolumn{2}{|c|}{ Tahun 2006} & \multicolumn{2}{|c|}{ Tahun 2009} & \multicolumn{2}{|c|}{ Tahun 2012} & \multicolumn{2}{|c|}{ Tahun 2015} \\
\hline & & $\mathbf{m}^{2}$ & $\%$ & $\mathbf{m}^{2}$ & $\%$ & $\mathrm{~m}^{2}$ & $\%$ & $\mathbf{m}^{2}$ & $\%$ \\
\hline 1 & Air tawar & 556,489 & 0.21 & 613,544 & 0.23 & 507,285 & 0.19 & $8,006,410$ & 2.98 \\
\hline 2 & Semak belukar & $7,832,405$ & 2.92 & $6,320,268$ & 2.35 & $5,002,763$ & 1.86 & $34,000,600$ & 12.66 \\
\hline 3 & Hutan & $14,079,321$ & 5.24 & $109,620,348$ & 40.82 & $118,086,662$ & 43.97 & $87,913,921$ & 32.73 \\
\hline 4 & Pemukiman & $17,414,558$ & 6.48 & $29,531,593$ & 11.00 & $32,065,550$ & 11.94 & $42,594,800$ & 15.86 \\
\hline 5 & Padang rumput / Tanah Kosong & $1,413,535$ & 0.53 & $1,207,687$ & 0.45 & $9,045,965$ & 3.37 & $26,085,500$ & 9.71 \\
\hline 6 & Sawah irigasi & $76,638,552$ & 28.54 & $73,603,842$ & 27.41 & $62,433,564$ & 23.25 & $57,086,800$ & 21.26 \\
\hline 7 & Ladang & $150,639,971$ & 56.09 & $47,677,549$ & 17.75 & $41,433,042$ & 15.43 & $12,886,800$ & 4.80 \\
\hline & & $268,574,831$ & & $268,574,831$ & & $268,574,831$ & & $268,574,831$ & \\
\hline
\end{tabular}

Sumber: hasil analisa

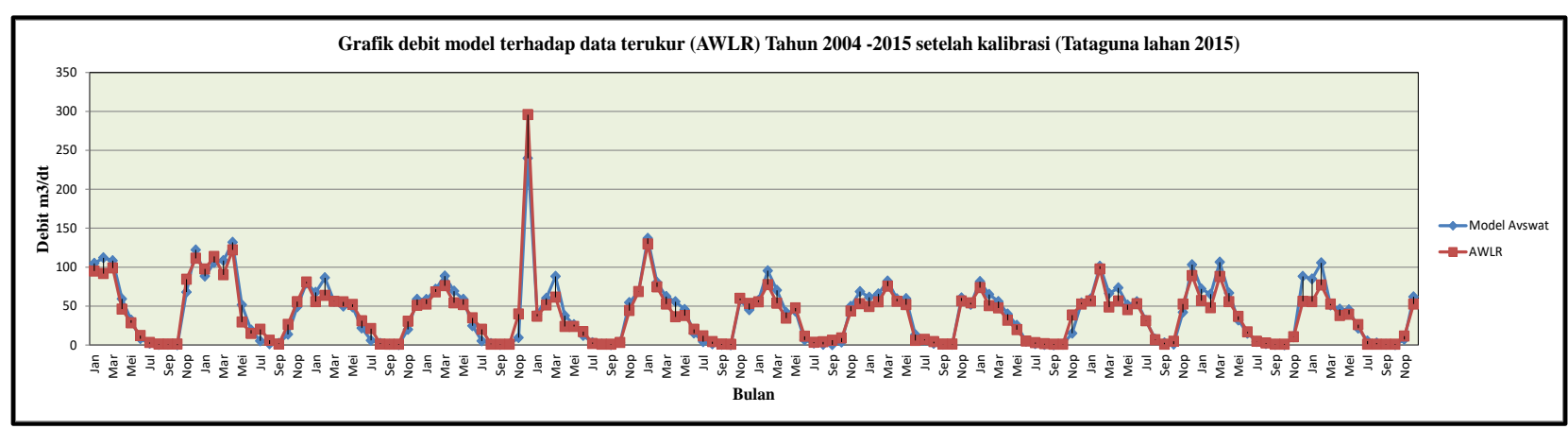

Gambar 5 Grafik Perbandingan Debit Model Terhadap Data Terukur (AWLR) Tahun 2004 - 2015 Setelah Kalibrasi (Tataguna Lahan 2015) Sumber: hasil analisa AVSWAT 2000

Tabel 4 Rekapitulasi Evaluasi Ketelitian Debit Model hasil Kalibrasi

\begin{tabular}{|l|c|c|c|c|}
\hline \multirow{2}{*}{\multicolumn{1}{|c|}{ Metode Evaluasi }} & \multicolumn{5}{|c|}{ Tataguna Lahan } \\
\cline { 2 - 5 } & $\mathbf{2 0 0 6}$ & $\mathbf{2 0 0 9}$ & $\mathbf{2 0 1 2}$ & $\mathbf{2 0 1 5}$ \\
\hline Analisis Regresi & 0.97 & 0.92 & 0.86 & 0.92 \\
\hline Mean Absolut Error (MAE) & 5.35 & 6.06 & 8.14 & 7.60 \\
\hline Koefisien Performance (CP) & 0.04 & 0.07 & 0.13 & 0.07 \\
\hline Nash-Sutclife Efisiensi (NSE) & 0.95 & 0.93 & 0.89 & 0.91 \\
\hline
\end{tabular}

Sumber : Hasil perhitungan

Dari Tabel 4, dari beberapa tataguna lahan metode analisis regresi diperoleh nilai koefisien diantara $0,6<\mathrm{R}<1$. Dimana nilai $\mathrm{R}$ dari perbandingan debit model dengan debit terukur AWLR secara keseluruhan memiliki hubungan positif baik.

Sedangkan metode Mean Absolut Error (MAE)digunakan untuk mendeskripsikan kesalahan rata-rata dari kesalahan absolut dalam sebuah pemodelan. Semakin kecil nilai MAE, maka semakin baik prediksi yang dihasilkan (marissa. Dkk, 2013). Dari Tabel 4 menunjukkan bahwa hasil simulasi setelah kalibrasi cukup baik.

Metode Koefisien Performance (CP) berfungsi mengevaluasi perbedaan prosedur statistik prediksi hidrologi aliran air. Dari Tabel 4 hasil uji korelasi data diperoleh nilai CP dari perbandingan debit model dengan debit terukur
AWLR secara keseluruhan masuk klasifikasi sempurna.

Nilai efisiensi Nash-Sutcliffe (NSE) menyatakan seberapa tepat perbandingan antara debit hasil simulasi dengan debit pengamatan. Nilai optimum NSE adalah mendekati 1. Dari Tabel 4 nilai NSE di diketahui bahwa nilai NSE model AVSWAT sudah sangat layak untuk digunakan keperluan studi selanjutnya.

Berdasarkan hasil simulasi AVSWAT 2000, maka besaran nilai debit maksimum sub DAS Jeroan pada kondisi tatagunalahan tahun 2006, 2009, 2012 dan 2015 terjadi debit puncak/maksimum ditahun 2007 besarannya disajikan pada Tabel 5.

\section{Analisa Debit Kala Ulang Banjir}

Untuk menghitung debit banjir rancangan pada sub DAS Jeroan dan Uneng digunakan hidrograf satuan sintetik Nakayasu. Perhitungan hidrograf ini digunakan untuk mendukung pemodelan hidrolika dengan menggunakan program HEC-RAS. Data-data yang digunakan dalam analisa debit banjir tersebut disamping data hujan juga menggunakan data lainnya seperti data kondisi fisik sungai serta karakteristik DAS. Hasil perhitungan debit 
puncak banjir dengan metode Nakayasu dapat dilihat pada Tabel 6.

Tabel 5 Rekapitulasi Debit Puncak / Maksimum sub DAS Jeroan (Hasil Model)

\begin{tabular}{|c|c|c|c|c|}
\hline \multirow{2}{*}{ Tahun } & \multicolumn{5}{|c|}{ Tataguna Lahan } \\
\cline { 2 - 5 } & $\mathbf{2 0 0 6}$ & $\mathbf{2 0 0 9}$ & $\mathbf{2 0 1 2}$ & $\mathbf{2 0 1 5}$ \\
\hline 2004 & 115.33 & 114.93 & 103.13 & 122.14 \\
\hline 2005 & 146.64 & 122.86 & 119.41 & 131.87 \\
\hline 2006 & 72.83 & 94.48 & 78.36 & 86.40 \\
\hline 2007 & 295.80 & 200.89 & 171.81 & 239.82 \\
\hline 2008 & 70.10 & 66.87 & 60.33 & 88.14 \\
\hline 2009 & 130.08 & 136.76 & 110.72 & 136.97 \\
\hline 2010 & 82.87 & 78.41 & 97.25 & 95.45 \\
\hline 2011 & 93.40 & 89.71 & 82.03 & 82.16 \\
\hline 2012 & 83.16 & 79.58 & 75.25 & 81.50 \\
\hline 2013 & 100.77 & 104.61 & 103.92 & 103.24 \\
\hline 2014 & 90.45 & 95.30 & 83.68 & 106.46 \\
\hline 2015 & 78.30 & 80.88 & 80.11 & 105.56 \\
\hline Maksimum & $\mathbf{2 9 5 . 8 0}$ & $\mathbf{2 0 0 . 8 9}$ & $\mathbf{1 7 1 . 8 1}$ & $\mathbf{2 3 9 . 8 2}$ \\
\hline
\end{tabular}

Sumber: hasil analisa

Dari Tabel 6 disimpulkan bahwa untuk debit historis yang pernah terjadi sebesar $295.75 \mathrm{~m}^{3} / \mathrm{dt}$ (data terukur AWLR Jeroan tahun 2007) yang mendekati kala ulang 25 tahun.
Tabel 6 Rekapitulasi Debit Banjir, Debit Maksimum AWLR dan Model AVSWAT

\begin{tabular}{|c|c|c|c|c|c|c|c|c|}
\hline \multirow{2}{*}{ No } & \multirow{2}{*}{ SUB DAS } & \multicolumn{7}{|c|}{ Qkala ulang ( $\mathrm{m}^{3} /$ detik) } \\
\hline & & Q,th & Qth & $Q_{10}$ th & $\mathrm{Q}_{0}$ th & $\mathrm{Q}_{2}$ th & $Q_{\text {soth }}$ & Qrooth \\
\hline 1 & Jercan & 208.95 & 254.53 & 276.21 & 293.37 & 296.93 & 308.86 & 318.49 \\
\hline 2 & Uneng & 149.12 & 163.93 & 175.21 & 188.05 & 190.73 & 203.10 & 216.07 \\
\hline \multicolumn{9}{|c|}{ Debit Maximum } \\
\hline 3 & \multirow{2}{*}{\multicolumn{3}{|c|}{$\begin{array}{l}\text { Debit pengukuran AWLR } \\
\text { DebitModel AVS WAT }\end{array}$}} & \multicolumn{2}{|c|}{ Tahmen 2007} & 295.75 & & \\
\hline 4 & & & & Tahos & 2007 & 295.80 & & \\
\hline
\end{tabular}

Sumber: hasil analisa

Sehingga running banjir di sub DAS Jeroan direncanakan menggunakan kala Ulang 25 tahun dengan debit $296,93 \mathrm{~m}^{3} / \mathrm{dt}$, sedangkan untuk kala ulang sub DAS Uneng diestimasi kejadian banjir mendekati sub DAS Jeroan yaitu kala Ulang 25 tahun sebesar $190.73 \mathrm{~m}^{3} / \mathrm{dt}$. Sehingga dapat diilustrasikan pada Gambar 6 skema sistem sungai sub DAS Jeroan dengan $\mathrm{Q}_{25}$ th.

\section{Analisa Kapasitas Sungai Eksisting}

Analisis kapasitas sungai pada kajian ini menggunakan bantuan program HEC-RAS 5.0.1. dengan skenario dapat dilihat pada Tabel 7 sedangkan untuk skema geometri (memanjang dan melintang) sungai jeroan dan Uneng dapat dilihat pada Gambar 7.

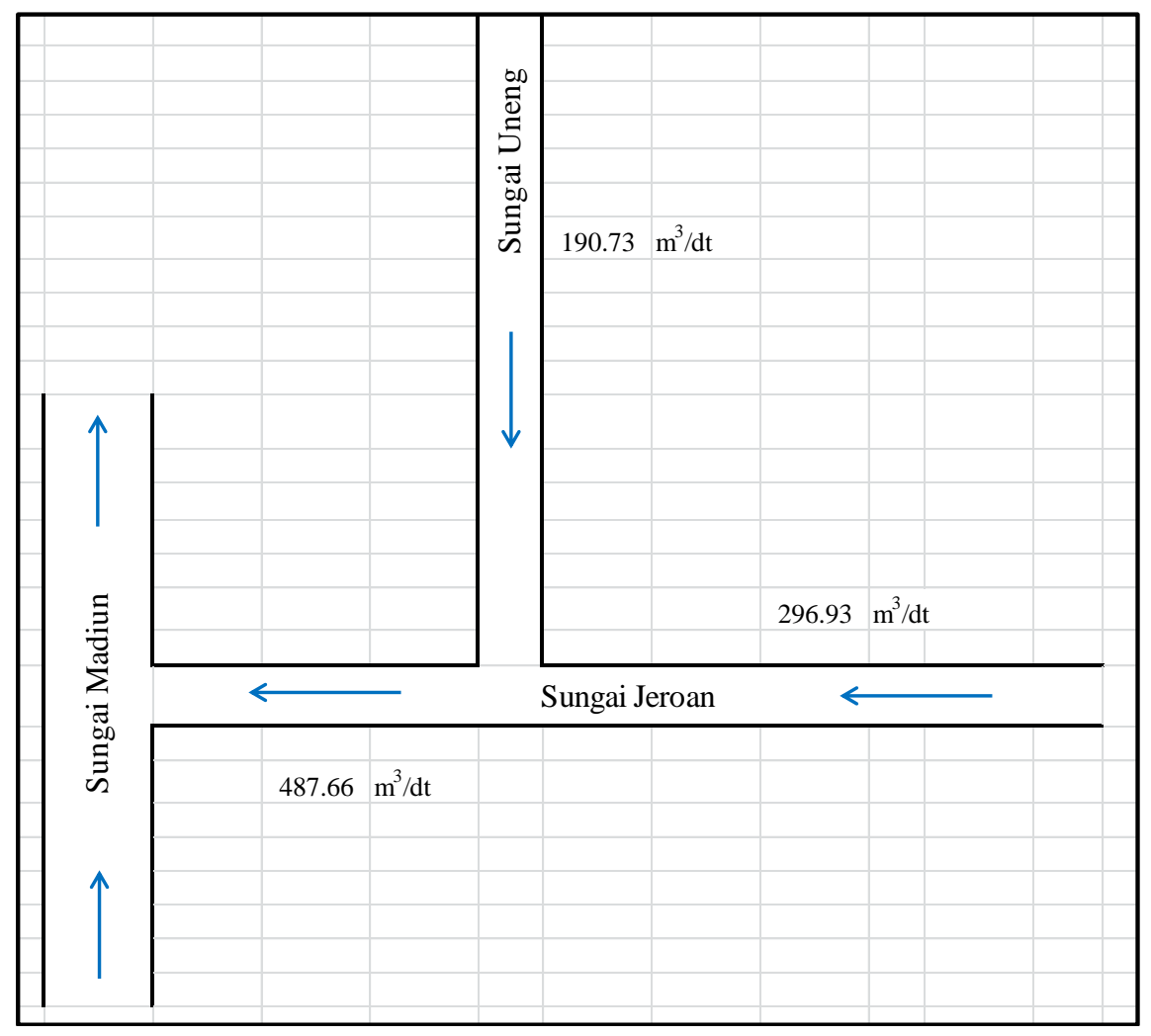

Gambar 6 Sistem Debit Banjir $\mathrm{Q}_{25}$ Sub DAS Jeroan dan Uneng 


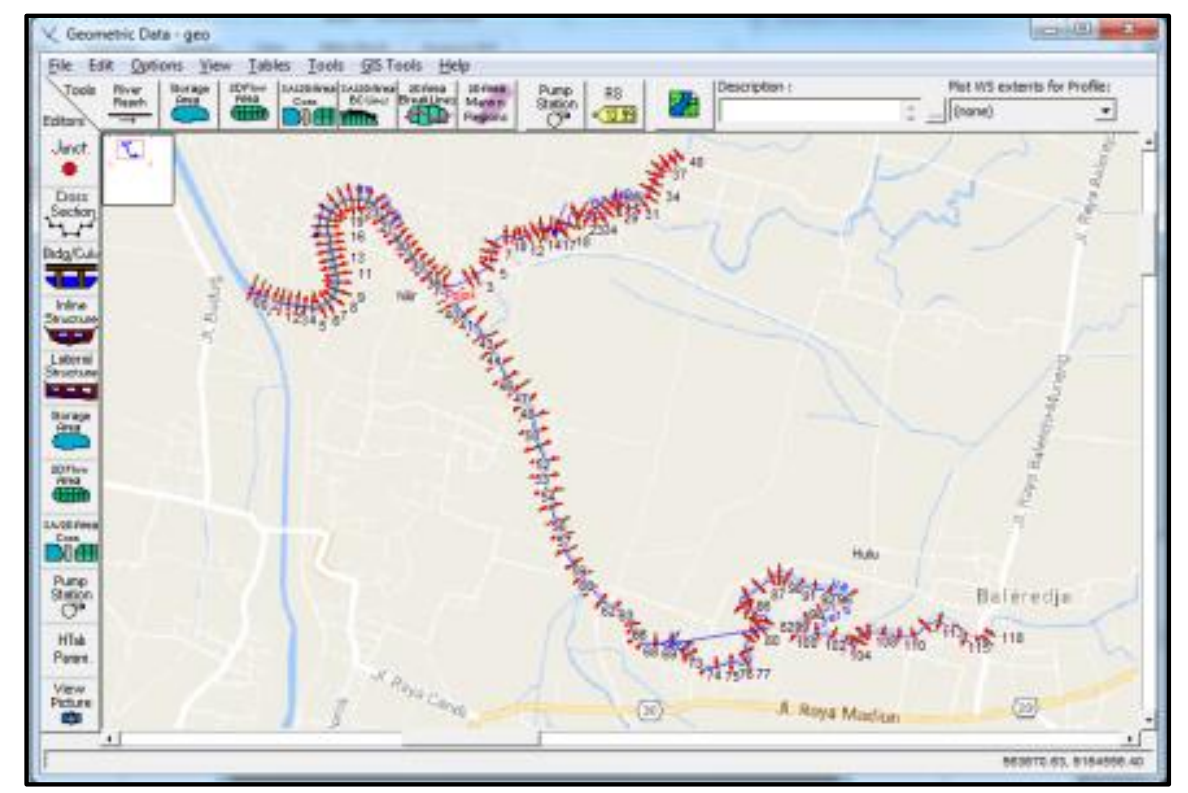

Gambar 7 Skema Geometri Sungai Jeroan dan Uneng Sumber: input HEC-RAS 5.0.1

\section{A. Skenario 1}

\section{Upstream}

Jeroan Hulu (patok 118) menggunakan syarat batas normal depth dengan slope 0.0005 , dan dengan input debit banjir $\mathrm{Q}_{25}$ tahun sebesar $296.93 \mathrm{~m}^{3} / \mathrm{dt}$. Uneng hulu (patok 40) menggunakan syarat batas normal depth dengan slope 0.0008 , dan dengan input debit banjir $\mathrm{Q}_{25}$ tahun sebesar $190.73 \mathrm{~m}^{3} / \mathrm{dt}$.

Downstream

Jeroan hilir (patok 0) menggunakan syarat batas known water surface berdasarkan elevasi tertinggi pertemuan sungai Madiun dan Jeroan yaitu + 55.22 (hasil wawancara dengan penduduk). Dan dengan input debit gabungan antara debit Jeroan hulu dan Uneng hulu sebesar $487.66 \mathrm{~m}^{3} / \mathrm{dt}$.

\section{B. Skenario 2}

Pada skenario ini bertujuan untuk mengetahui sebaran genangan akibat luapan sungai Jeroan dan Uneng, untuk itu dilakukan unsteady flow dalam proses running HEC-RAS 5.0.1.

Upstream

Upstream Jeroan menggunakan input flow hydrograph debit banjir Nakayasu $\mathrm{Q}_{25}$ tahun sub DAS Jeroan. Upstream Uneng menggunakan flow hydrograph debit banjir Nakayasu $\mathrm{Q}_{25}$ tahun. Sub DAS Uneng

Downstream

Downstream menggunakan input stage hydrograph berdasarkan elevasi tertinggi pertemuan sungai Madiun dan Jeroan yaitu + 55.22 .

Tabel 7 Skenario dalam Menjalankan Running Program HEC-RAS

\begin{tabular}{|c|c|c|c|c|}
\hline No & Ruas & Kondis Batas Hulu & Kondisi Batas Hilir & \multirow{2}{*}{ Kondisi Pengaliran } \\
\hline \multirow{2}{*}{1} & Jeroan Hulu - Junction & Normal Depth (slope =0.0005) & Junction & \multirow{2}{*}{ Steady Flow, Mixed Flow } \\
\cline { 2 - 4 } & Uneng Hulu - Junction & Normal Depth (slope =0.0008) & Junction & \multirow{2}{*}{ Known WS (+ 55.22) } \\
\cline { 2 - 4 } & Junction - Jeroan Hilir & Junction & Junction & \multirow{2}{*}{ Junction } \\
\hline \multirow{2}{*}{2} & Jeroan Hulu - Junction & Flow Hydrograph & Stage Hydrograph & \\
\cline { 2 - 5 } & Uneng Hulu - Junction & Flow Hydrograph & & \multicolumn{2}{|c|}{} \\
\cline { 2 - 5 } & Junction - Jeroan Hilir & Junction & &
\end{tabular}

Sehingga diperoleh hasil profil muka air Gambar 8 dan Tabel 8, berikut: 


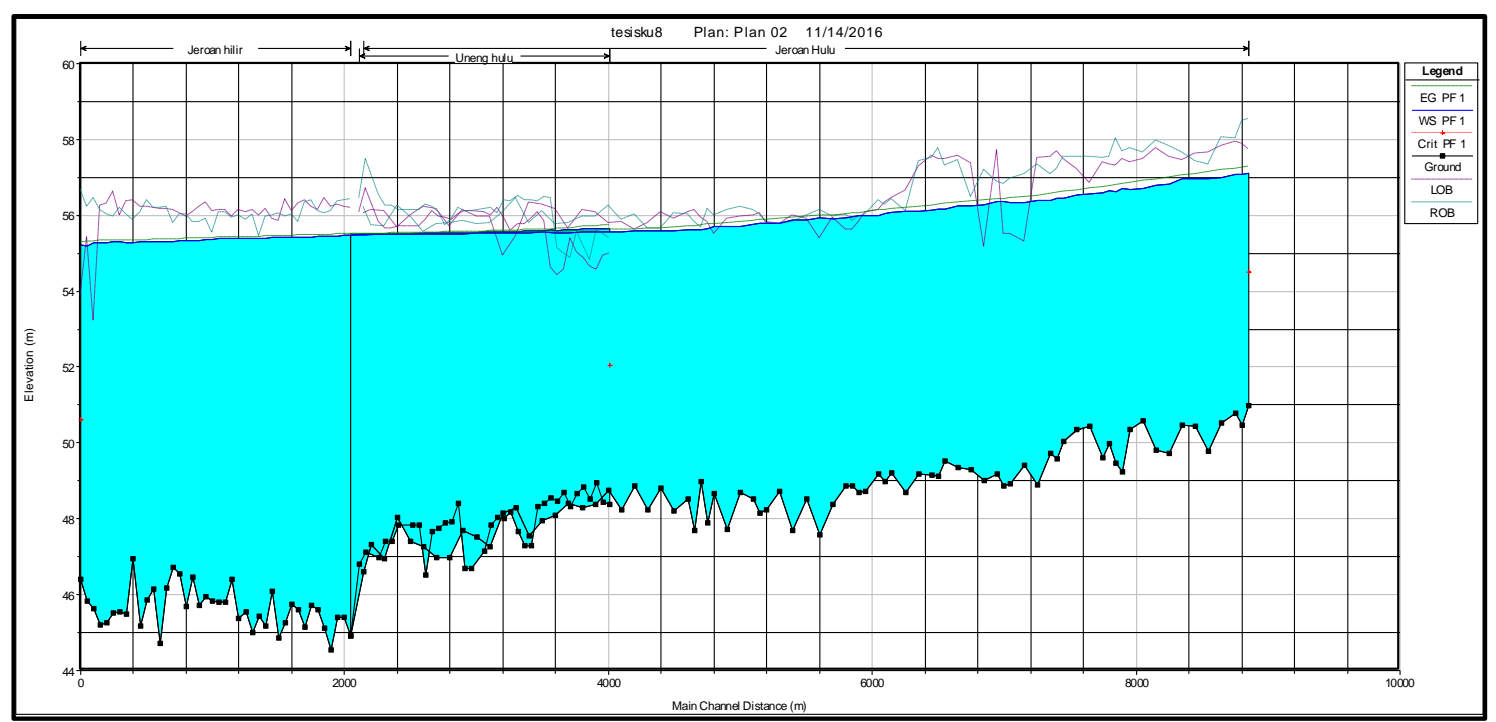

Gambar 8 Profil Muka Air Sungai Jeroan dan Uneng debit $\mathrm{Q}_{25}$ th Sumber: hasil HEC-RAS 5.0.1

Tabel 8 Rekapitulasi Analisa Profil Muka Air Hasil Running HEC-RAS 5.0.1

\begin{tabular}{|c|c|c|c|c|c|c|c|}
\hline \multirow{3}{*}{ Sungai } & \multirow{3}{*}{ Patok } & \multirow[b]{2}{*}{$\mathrm{Q}_{25}$ th } & \multirow{2}{*}{$\begin{array}{c}\text { Elevasi } \\
\text { Dasar } \\
\text { Sungai } \\
\end{array}$} & \multicolumn{2}{|c|}{ Elevasi Tanggul } & \multirow{2}{*}{$\begin{array}{c}\text { Elevasi } \\
\text { Muka } \\
\text { Air } \\
\end{array}$} & \multirow[b]{2}{*}{ Kondisi Ai } \\
\hline & & & & Kiri & Kanan & & \\
\hline & & $\left(\mathrm{m}^{3} / \mathrm{s}\right)$ & (m) & (m) & (m) & (m) & \\
\hline Uneng & 40 & 190.73 & 48.37 & 54.98 & 55.38 & 55.66 & Meluap \\
\hline Uneng & 39 & 190.73 & 48.43 & 54.93 & 55.51 & 55.66 & Meluap \\
\hline Uneng & 38 & 190.73 & 48.95 & 54.56 & 55.6 & 55.66 & Meluap \\
\hline Uneng & 37 & 190.73 & 48.52 & 54.65 & 54.82 & 55.65 & Meluap \\
\hline Uneng & 36 & 190.73 & 48.84 & 54.88 & 55.18 & 55.64 & Meluap \\
\hline Uneng & 35 & 190.73 & 48.66 & 55.03 & 55.57 & 55.63 & Meluap \\
\hline Uneng & 34 & 190.73 & 48.31 & 55.38 & 54.89 & 55.62 & Meluap \\
\hline Uneng & 33 & 190.73 & 48.7 & 54.57 & 55 & 55.61 & Meluap \\
\hline Uneng & 32 & 190.73 & 48.47 & 54.42 & 55.13 & 55.59 & Meluap \\
\hline Uneng & 31 & 190.73 & 48.56 & 54.63 & 56.46 & 55.61 & Meluap \\
\hline Jeroan & 97 & 296.93 & 49.4 & 55.31 & 57.08 & 56.34 & eluap \\
\hline Jeroan & 96 & 296.93 & 48.92 & 55.52 & 56.96 & 56.35 & eluap \\
\hline Jeroan & 95 & 296.93 & 48.88 & 55.52 & 56.82 & 56.36 & Meluap \\
\hline Jeroan & 93 & 296.93 & 49.01 & 55.16 & 57.2 & 56.28 & Meluap \\
\hline Jeroan & 81 & 296.93 & 48.7 & 55.81 & 55.95 & 56.01 & \\
\hline Jeroan & 80 & 296.93 & 48.86 & 55.62 & 55.85 & 55.95 & Meluap \\
\hline Jeroan & 79 & 296.93 & 48.86 & 55.62 & 56.02 & 55.94 & Meluap \\
\hline Jeroan & 77 & 296.93 & 47.58 & 55.39 & 56.13 & 55.94 & Meluap \\
\hline Jeroan & 75 & 296.93 & 47.68 & 55.99 & 55.83 & 55.87 & Meluap \\
\hline Jeroan & 74 & 296.93 & 48.72 & 55.77 & 55.75 & 55.8 & Meluap \\
\hline Jeroan & 73 & 296.93 & 48.23 & 55.82 & 55.79 & 55.8 & Meluap \\
\hline Jeroan & 68 & 296.93 & 48.67 & 55.52 & 55.98 & 55.7 & Meluap \\
\hline Jeroan & 51 & 296.93 & 48.29 & 55.44 & 56.44 & 55.54 & Meluap \\
\hline Jeroan & 50 & 296.93 & 48.14 & 54.94 & 56.07 & 55.54 & Meluap \\
\hline Jeroan & 0.4 & 487.66 & 45.62 & 53.22 & 56.46 & 55.28 & Meluap \\
\hline Jeroan & 0 & 487.66 & 46.39 & 53.88 & 56.67 & 55.22 & Meluap \\
\hline
\end{tabular}

Sumber: hasil HEC-RAS 5.0.1

Tabel 9 Tabulasi Luas dan Volume Genangan

\begin{tabular}{|c|l|r|}
\hline No & \multicolumn{1}{|c|}{ Keterangan } & \multicolumn{1}{|c|}{ Besarannya } \\
\hline 1 & Luas Genangan $\left(\mathrm{m}^{2}\right)$ & $5,847,096$ \\
\hline 2 & Tinggi Genangan Rata-rata $(\mathrm{m})$ & 1.496 \\
\hline 3 & Volume Genangan $\left(\mathrm{m}^{3}\right)$ & $8,748,236$ \\
\hline 4 & Volume Kapasitas Sungai $\left(\mathrm{m}^{3}\right)$ & $3,578,285$ \\
\hline 5 & Volume Genangan di lahan $\left(\mathrm{m}^{3}\right)$ & $5,169,952$ \\
\hline
\end{tabular}

Sumber: hasil analisa

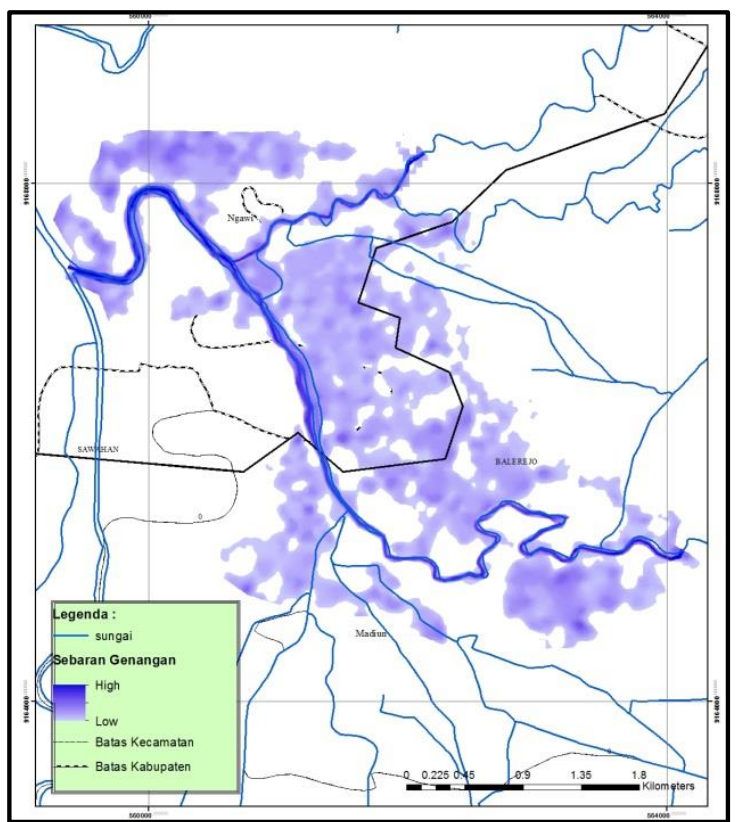

Gambar 9 Sebaran Genangan Hasil Running HEC-RAS 5.0.1

Sumber: hasil HEC-RAS 5.0.1

Sedangkan dari Gambar 9 dan Tabel 9 dapat diketahui bahwa volume genangan dilahan sebesar $5.169 .952 \mathrm{~m}^{3}$ dengan tinggi genangan rata-rata $1,496 \mathrm{~m}$ sehingga kapasitas sungai tidak dapat menampung debit banjir $\mathrm{Q}_{25}$ tahun pada beberapa patok, sehingga perlu adanya pengendalian banjir sungai Jeroan.

\section{Pengendalian Banjir}

Pengendalian banjir dilakukan dihulu dan hilir sub DAS Jeroan. Dihulu dengan perencanaan bendungan dan dihilir dengan normalisasi serta pembuatan tanggul sungai. 


\section{Perencanaan Bendungan}

Lokasi bendungan dapat dilihat pada Gambar 10, bendungan 1 terletak didesa Tawangrejo, Kecamatan Gemarang, Kabupaten Madiun dan bendungan 2 terletak didesa Sumberbendo, Kecamatan Saradan, Kabupaten Madiun.

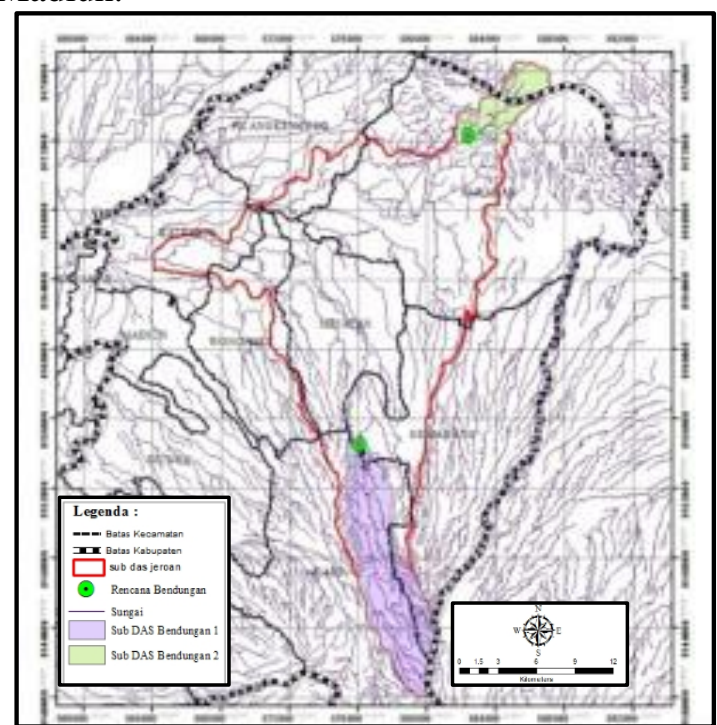

Gambar 10 Peta Rencana Lokasi Bendungan di

$$
\text { Sub DAS Jeroan }
$$

Sumber: Dinas PU Pengairan Kab. Madiun
Tabel 10 Tabel Hasil Perhitungan Perencanaan Bendungan

\begin{tabular}{|l|c|c|}
\hline \multicolumn{1}{|c|}{ Keterangan } & Bendungan 1 & Bendungan 2 \\
\hline Tampungan Waduk $\left(\mathrm{m}^{3}\right)$ & 35,153 juta & 10,811 juta \\
\hline Q1000 Ttahun $\left(\mathrm{m}^{3} / \mathrm{dt}\right)$ & 102,192 & 40,11 \\
\hline Tinggi Ambang $(\mathrm{m})$ & 67,93 & 31,8 \\
\hline Elevasi Dasar & +209 & +185 \\
\hline Elevasi Crest Spilway & $+276,93$ & $+216,80$ \\
\hline Q outflow $\left(\mathrm{m}^{3} / \mathrm{dt}\right)$ & 30 & 9,10 \\
\hline H Outflow $(\mathrm{m})$ & 0,98 & 0,61 \\
\hline Elevasi MAT & $+277,91$ & $+217,41$ \\
\hline
\end{tabular}

Sumber: hasil analisa

Tabel 10 menunjukan hasil perhitungan perencanaan bendungan di 2 (dua) lokasi. Dengan adanya bendungan maka debit banjir Sungai Jeroan dapat direduksi sebesar $91,32 \mathrm{~m}^{3} / \mathrm{dt}$ (untuk lebih jelasnya dapat dilihat pada Gambar 11)

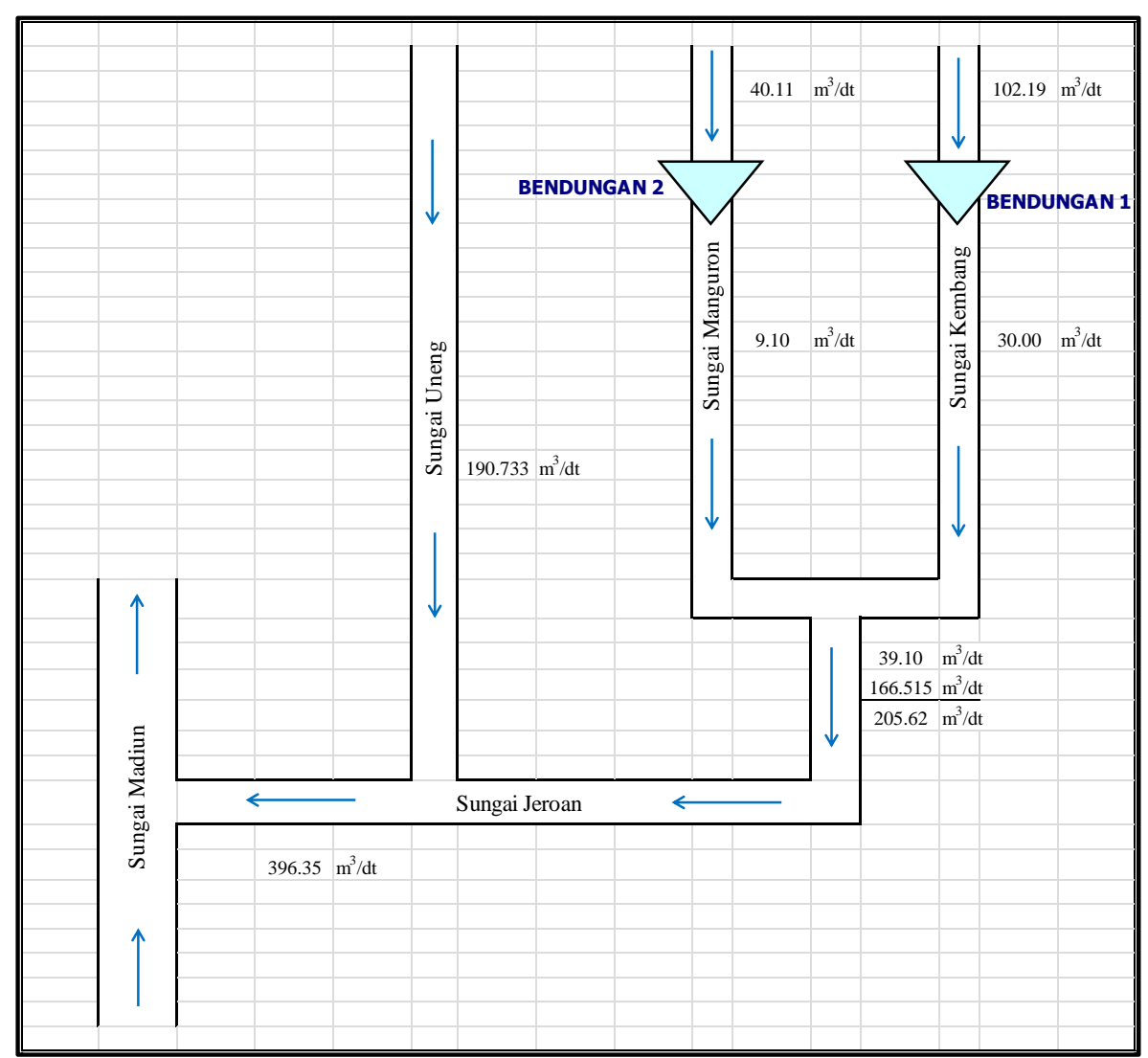

Gambar 11 Sistem Debit Banjir $\mathrm{Q}_{25}$ Sub DAS Jeroan Setelah Ada Bendungan 
Dengan skenario sesuai Gambar 11 dengan bantuan program HEC-RAS 5.0.1 maka didapat profil muka air Gambar 12.

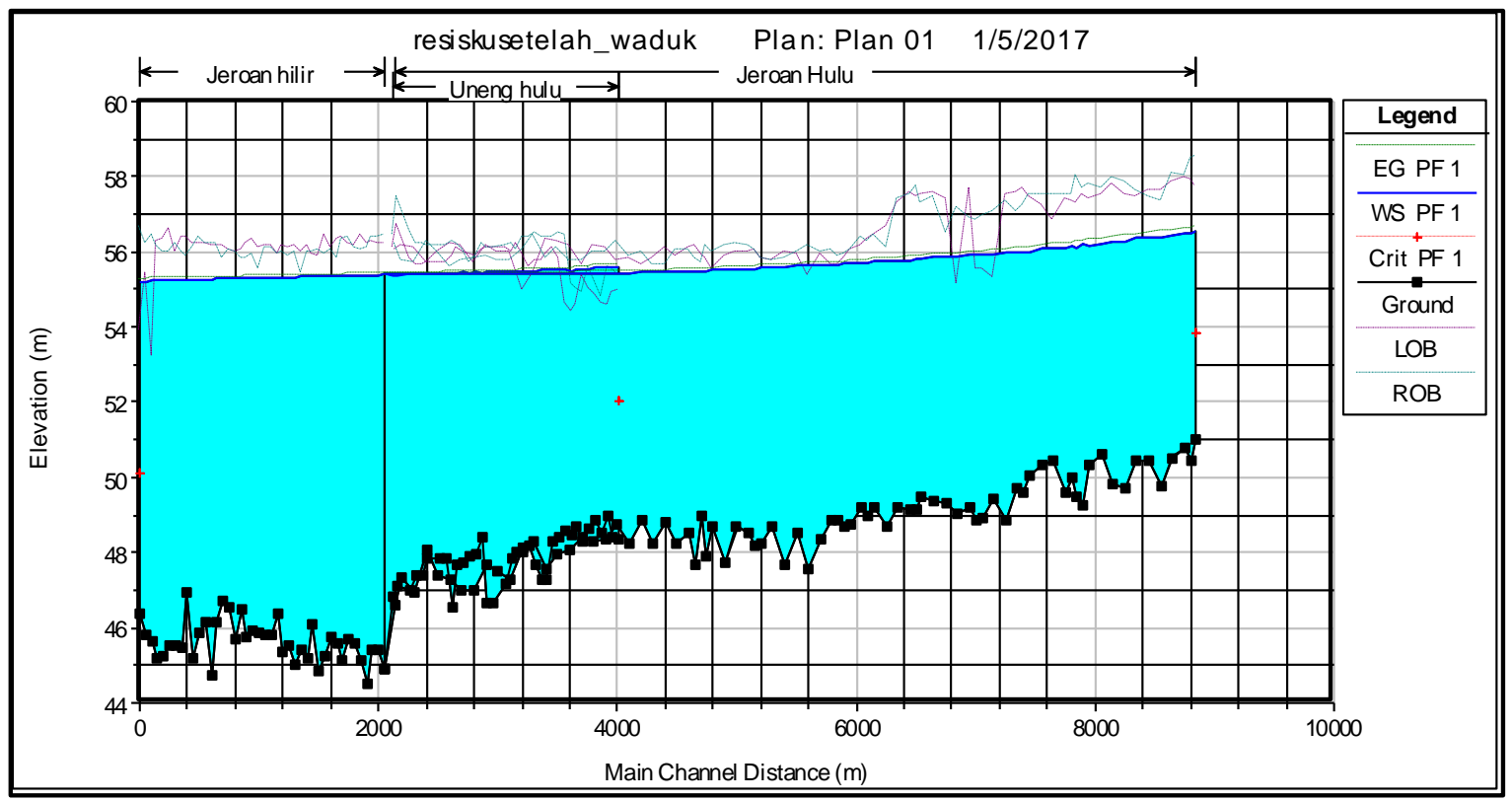

Gambar 12 Potongan Memanjang Profil Muka Air Hasil Running HEC-RAS Setelah ada Bendungan

Sumber: hasil HEC-RAS 5.0.1

Tabel 11 Rekapitulasi Hasil Reduksi Pengendalian Banjir Sungai Jeroan

\begin{tabular}{|c|l|r|r|r|r|}
\hline No & \multicolumn{1}{|c|}{ Keterangan } & $\begin{array}{c}\text { Sebelum ada } \\
\text { Penanganan }\end{array}$ & \multicolumn{1}{|c|}{$\begin{array}{c}\text { Penanganan } \\
\text { dengan } \\
\text { Bendungan }\end{array}$} & Reduksi & $\begin{array}{c}\text { Reduksi } \\
(\%)\end{array}$ \\
\hline 1 & Luas Genangan $\left(\mathrm{m}^{2}\right)$ & $5,847,096$ & $5,545,951$ & 301,145 & 5.15 \\
\hline 2 & Tinggi Genangan Rata-rata $(\mathrm{m})$ & 1.496 & 1.110 & 0.386 & 25.81 \\
\hline 3 & Volume Genangan $\left(\mathrm{m}^{3}\right)$ & $8,748,236$ & $6,156,006$ & $2,592,231$ & 29.63 \\
\hline 4 & Volume Kapasitas Sungai $\left(\mathrm{m}^{3}\right)$ & $3,578,285$ & $3,578,285$ & - & - \\
\hline 5 & Volume Genangan di lahan $\left(\mathrm{m}^{3}\right)$ & $5,169,952$ & $2,577,721$ & $2,592,231$ & 50.14 \\
\hline
\end{tabular}

Sumber : hasil analisa

Dari Tabel 11 diatas dapat diambil analisa bahwa telah terjadi penurunan tinggi genangan rata-rata dan volume genangan dilahan, setelah adanya penanganan berupa bendungan. Sehingga dapat disimpulkan bahwa dengan adanya penanganan berupa bendungan dapat mereduksi genangan dilahan sebesar $50,14 \%$.

\section{Normalisasi dan Pembuatan Tanggul Sungai}

Normalisasi sungai dimaksudkan dengan melakukan perbaikan penampang sungai yang kecil (Arifuddin, 2014). Penentuan lebar rencana sungai adalah merupakan salah satu tahap perencanaan perbaikan dan pengaturan sungai yang paling penting.

Sedangkan tanggul dibuat sebagai sarana untuk meng-cover debit banjir sungai. Tabel 12 merupakan rencana normalisasi dan pembuatan tanggul sebagai penanganan banjir dihilir sub DAS Jeroan.

Dari Gambar 13 didapatkan bahwa dengan adanya pengendalian banjir dihilir maka luapan banjir sungai jeroan dapat direduksi secara keseluruhan. 
Tabel 12 Rekapitulasi Pengendalian Banjir Sungai Jeroan dihilir

\begin{tabular}{|c|c|c|c|c|c|c|c|c|}
\hline \multirow{3}{*}{ Sungai } & \multirow{3}{*}{ Patok } & \multirow{3}{*}{$\begin{array}{c}\text { Jarak } \\
(\mathrm{m})\end{array}$} & \multirow{3}{*}{ Penanggulangan Banjir } & \multicolumn{2}{|c|}{ Normalisasi } & \multicolumn{3}{|c|}{ Tanggul } \\
\hline & & & & \begin{tabular}{|c|} 
Lebar \\
Eksisting
\end{tabular} & \begin{tabular}{|c|} 
Lebar \\
Rencana
\end{tabular} & $\begin{array}{c}\text { Rencana } \\
\text { Lebar Puncak }\end{array}$ & $\begin{array}{c}\text { Tinggi } \\
\text { Tanggul Kiri }\end{array}$ & $\begin{array}{c}\text { Tinggi Tanggul } \\
\text { Kanan }\end{array}$ \\
\hline & & & & $(\mathrm{m})$ & $(\mathrm{m})$ & (m) & (m) & (m) \\
\hline Uneng & 40 & 50 & Normalisasi dan Tanggul & 32.65 & 60 & 3 & 1.2 & 1.2 \\
\hline Uneng & 39 & 50 & Normalisasi dan Tanggul & 34.4 & 60 & 3 & 1.2 & 1.2 \\
\hline Uneng & 38 & 50 & Normalisasi dan Tanggul & 25.5 & 60 & 3 & 1.2 & 1.2 \\
\hline Uneng & 37 & 50 & Normalisasi dan Tanggul & 33 & 60 & 3 & 1.2 & 1.2 \\
\hline Uneng & 36 & 50 & Normalisasi dan Tanggul & 36.5 & 60 & 3 & 1.2 & 1.2 \\
\hline Uneng & 35 & 50 & Normalisasi dan Tanggul & 34.5 & 60 & 3 & 1.2 & 1.2 \\
\hline Uneng & 34 & 50 & Normalisasi dan Tanggul & 36 & 60 & 3 & 1.2 & 1.2 \\
\hline Uneng & 33 & 50 & Normalisasi dan Tanggul & 31 & 60 & 3 & 1.2 & 1.2 \\
\hline Uneng & 32 & 50 & Normalisasi dan Tanggul & 35.8 & 60 & 3 & 1.2 & 1.2 \\
\hline Uneng & 31 & 50 & Normalisasi dan Tanggul & 41.8 & 60 & 3 & & 1.2 \\
\hline Jeroan & 97 & 100 & Tanggul & & & 3 & & 1.8 \\
\hline Jeroan & 96 & 50 & Tanggul & & & 3 & & 1.8 \\
\hline Jeroan & 95 & 50 & Tanggul & & & 3 & & 1.8 \\
\hline Jeroan & 93 & 100 & Tanggul & & & 3 & & 1.8 \\
\hline Jeroan & 80 & 50 & Tanggul & & & 3 & & 1.8 \\
\hline Jeroan & 79 & 100 & Tanggul & & & 3 & & 1.8 \\
\hline Jeroan & 77 & 100 & Tanggul & & & 3 & & 1.8 \\
\hline Jeroan & 50 & 100 & Tanggul & & & 3 & & 1.8 \\
\hline Jeroan & 0.4 & 50 & Tanggul & & & 3 & & 2 \\
\hline Jeroan & 0 & 122 & Tanggul & & & 3 & & 2.4 \\
\hline
\end{tabular}

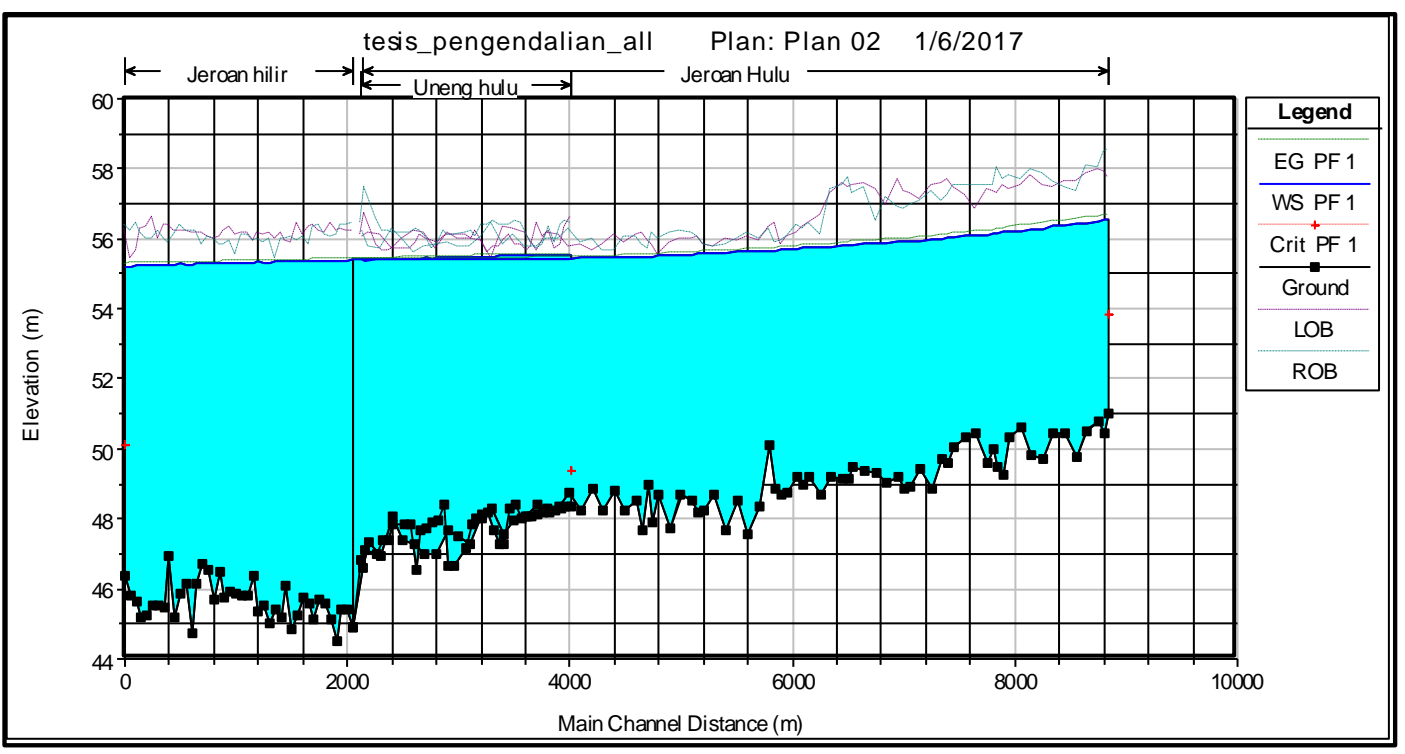

Gambar 13 Potongan Memanjang Profil Muka Air Hasil Running HEC-RAS Setelah Pengendalian Banjir Sungai Jeroan dihilir Sumber: hasil HEC-RAS 5.0.1

\section{KESIMPULAN}

Berdasarkan hasil studi ini, maka dapat disimpulkan sebagai berikut:

1. Berdasarkan analisis peta tataguna lahan tahun 2006, 2009, 2012 dan 2015 telah terjadi fluktuasi perubahan penggunaan lahan di sub DAS Jeroan yang diindikasikan dengan naik dan turunnya luas penggunaan lahan. Sehingga berdampak pada berubahnya respon sub DAS Jeroan terhadap hujan. Hal ini ditunjukkan pada perubahan debit puncak yang terjadi pada tahun 2007 pada tataguna lahan tahun 2006, 2009, 2012 dan 2015 sebesar $295,80 \mathrm{~m}^{3} / \mathrm{dt}, 200,89 \mathrm{~m}^{3} / \mathrm{dt}, 171,81$ $\mathrm{m}^{3} / \mathrm{dt}, 239,82 \mathrm{~m}^{3} / \mathrm{dt}$.

2. Data terukur AWLR Jeroan periode tahun 2004 - 2015 diperoleh data debit terbesar tanggal 29 Desember 2007 sebesar 295,75 $\mathrm{m}^{3} / \mathrm{dt}$, dimana dengan perhitungan debit banjir metode HSS Nakayasu mendekati debit banjir kala ulang 25 tahun $=296,93$ 
$\mathrm{m}^{3} / \mathrm{dt}$. sehingga dalam kajian ini perhitungan selanjutnya menggunakan debit banjir kala ulang 25 tahun $\left(\mathrm{Q}_{25}\right.$ th).

3. Dari hasil pemodelan HEC-RAS 5.0.1 dengan skenario sungai jeroan input debit banjir kala ulang 25 tahun $\left(\mathrm{Q}_{25}\right.$ th $)$ sebesar $296.93 \mathrm{~m}^{3} / \mathrm{dt}$ dan sungai uneng input debit banjir kala ulang 25 tahun $\left(\mathrm{Q}_{25}\right.$ th) sebesar $190.73 \mathrm{~m}^{3} / \mathrm{dt}$ serta pada hilir dibatasi elevasi tertinggi pertemuan sungai Madiun dan Jeroan yaitu +55.22 , maka kapasitas sungai Jeroan dan Uneng tidak dapat menampung. Hal ini dapat dilihat pada patok P.0, P.0.4, P.50-P.51, P.68, P.73P.75, P.77, P.79-P.81, P.93, P.95-P.97 untuk sungai Jeroan, sedangkan untuk sungai Uneng P.31-P.40. Akibat kapasitas sungai tidak dapat menampung maka mengakibatkan genangan dilahan sebesar $5.169 .952 \mathrm{~m}^{3}$.

4. Pengendalian banjir dilakukan dengan pembuatan bendungan dihulu dan normalisasi serta pembuatan tanggul dihilir Sub DAS Jeroan. Perencanaan bendungan di 2 (dua) lokasi dihulu sub DAS Jeroan dapat mereduksi debit banjir kala ulang 25 tahun $\left(\mathrm{Q}_{25}\right.$ th $)$ menjadi 205,516 $\mathrm{m}^{3} / \mathrm{dt}$. Setelah dilakukan running HEC-RAS volume genangan di lahan menjadi $2.577 .721 \mathrm{~m}^{3}$, sehingga dengan adanya pengendalian banjir berupa bendungan dapat mereduksi genangan akibat banjir sebesar 50,14\%. Penanganan dengan normalisasi serta pembuatan tanggul dihilir Sub DAS Jeroan secara efektif dapat mereduksi sisa dari luapan sungai Uneng dan Jeroan secara keseluruhan.

\section{DAFTAR PUSTAKA}

Arifuddin K, Rizal, 2014. "Studi Pengendalian Banjir Kali Wrati Kabupaten Pasuruan".

Chay Asdak, 2002, "Hidrologi dan Pengelolaan Daerah Aliran Sungai". Gajah Mada University press, Yogyakarta.

Gina, Putri V., 2013. Analisa Runoff Pada Sub Das Lematang Hulu. Jurusan Teknik Sipil Fakultas Teknik Universitas Sriwijaya.

Marissa Afla Syahran, Erwin Budi Setiawan dan Sri Suryani. 2013. "Analisis Perbandingan Sistem Rekomendasi dengan Faktorisasi Matriks dan Pearson Berbasis Collaborative Filtering Pada Web E-Commerce".

Istiarto, Gunawan Djati Wibowo. 2007. "Sistem Pengendalian Banjir Kali Juana". Dinamika Teknik Sipil Volume 7. Fakultas Teknik UMS.

Satya, M.T. 2014. "Studi Normalisasi Sungai Sampean Sebagai Upaya Pengendalian Banjir". Jurusan Teknik Pengairan Fakultas Teknik Universitas Brawijaya.

Soemarto, C. D. 1999. "Hidrologi Teknik". Usaha Nasional, Surabaya.

Sosrodarsono, S., Tominaga, M dan Gayo, M .1994. "Perbaikan dan Pengaturan Sungai". P.T. Pradnya Paramita, Jakarta.

Suhartanto, Ery. 2008. “ Panduan AVSWAT 2000 dan Aplikasinya di Bidang Teknik Sumber Daya Air". CV. Asrori, Malang.

Sulfandi. 2015. "Studi Pengaruh Perubahan Tataguna Lahan di DAS Mamasa Terhadap Usia Guna Waduk PLTA Bakaru". Jurusan Teknik Pengairan Fakultas Teknik Universitas Brawijaya. 